\title{
Assessment of Mothers' Needs for their Infants who have Cleft Lip and/or Palate
}

\author{
${ }^{1}$ Eslam Reda Fathy, ${ }^{2}$ Dr. Azza Abdel Moghny Attia \\ ${ }^{I}$ Demonstrator, Faculty of Nursing, Suez Canal University, Egypt \\ ${ }^{2}$ Assist. Professor of Pediatric Nursing, Faculty of Nursing, Cairo University, Egypt
}

\begin{abstract}
:
Background: Parents of babies born with clefts have many questions and concerns, including basic information regarding care especially feeding. Aim: the study aimed to assess mothers' needs for their infants who have cleft lip and/or palate. Methods: descriptive exploratory design was adopted in the current study, Sample: convenience sample of 50 mothers having infants with cleft lip and/or palate, Tools of data collection: Two tools were utilized for data collection; structured questionnaire sheet and infant physical and psychological needs assessment form. Results: slightly less than three quarter and about two third of the mothers were unaware how to prevent their infants from getting pneumonia and otitis media respectively. Slightly more than one quarter and more than one fifth of the mothers were unaware and do nothing to prevent complications of weight loss. In addition; more than one fifth and slightly more than one quarter of the mothers were not achieving satisfaction of warmth, comfort and sucking pleasure needs to their infants respectively. Conclusion: The study concluded that the main eminent needs of some of infants' mothers were inability to deal with their infants' health problems arise during care of their infants with orofacial defects and also some mothers did not satisfy the basic developmental needs of their infants. Recommendation: Developmental needs and health problems of infants with cleft lip and/or palate should be taken into considerations in planning for infants' care and an educational program should be designed and implemented for those infants' mothers. Further studies using large sample size are needed to generalize the study results.
\end{abstract}

Keywords: developmental needs, health, infants, mothers, orofacial defects (OFDs), otitis media, pneumonia, underweight.

\section{Introduction}

Oro-facial clefts (OFCs) remain a prominent health issue in developed and developing countries alike. With a worldwide prevalence of approximately 1.2/1000 live births; OFCs are the commonest craniofacial birth defects in humans ${ }^{[1]}$. Cleft lip (CL) and palate (CP) occurs in about 1 to 2 per 1000 births in the developed world. CL is about twice as common in males as females, while CP without CL is more common in females ${ }^{[2]}$. In a study done in Egypt (Ain Shams University hospital) during the period from year 1995 up to year 2009 about "congenital malformations prevalence among Egyptian children (from birth up to 18 years) and associated risk factors", the study results revealed that the CL and CP prevalence were 0.3/1000 among the study sample $[3]$.

In addition to the aesthetic disfigurement, a child with cleft lip and/or palate suffers substantial functional morbidity such as restricted maxillofacial growth, speech anomalies, swallowing and feeding difficulties, hearing loss and/or recurrent ear infections. Although not generally life-threatening, living with a cleft elicits a significant health burden ${ }^{[4]}$. Cleft may cause problems with feeding, ear disease, speech and socialization. Due to lack of suction, an infant with a cleft may have trouble feeding. But do all this problems finishes with surgical treatment. Individuals with cleft also face many middle ear infections which may eventually lead to hearing loss. The Eustachian tubes and external ear canals may be angled or tortuous. Babies with palatal clefts may have compromised hearing and therefore, if the baby cannot hear, it cannot try to mimic the sounds of speech. Because the lips and palate are both used in pronunciation, individuals with cleft usually need the aid of a speech therapist ${ }^{[5]}$.

Parents of babies born with clefts have many questions and concerns, including the cause of the birth defect, the health of the baby, basic information regarding care especially feeding, and the timing and sequence of operations and non-operative treatments that the child will undergo ${ }^{[6]}$. Mothers need to know everything when a child is born with a cleft lip/cleft palate. Parents may grieve for the loss of the ideal child that they expected. Parents may need assistance to view their infant as a whole person, rather than focusing solely on the physical defect ${ }^{[7]}$. Needs of mothers of infant child with cleft lip and/or palate were evaluated by ${ }^{[8]}$, the results concluded that, CLP information, especially on feeding, surgery, financial support and speech problems were very important for them. 
According to Erikson psychosocial development theory the infant is concerned with acquiring sense of trust while overcoming a sense of mistrust. The trust that develops is a trust of self, of others, and of the world. Infant "trust" that their feeding, comfort, stimulation, and caring needs will be met. The crucial element for the achievement of this task is the quality of both the parent (caregiver)-child relationship and the care the infant receives. The provision of food, warmth, and shelter by itself is inadequate for the development of a strong sense of self. The infant and parent must jointly learn to satisfactorily meet their needs for mutual regulation of frustration to occur. When this synchrony fails to develop, mistrust is the eventual outcome ${ }^{[9]}$.

Pediatric nurses should upgrading the mother's knowledge, raising awareness of mothers about the importance of follow up care with craniofacial team for promoting their children's health condition and periodical meetings are to be held with all mothers having cleft lip and palate children to discuss prevention methods and early detection of problems associated with the defect and different ways of management ${ }^{[10]}$.. From the researchers' clinical experience, it is observed that the mothers of affected infants are unable to feed their infants well especially with cleft palate and the risk for aspiration is very high, therefore the infants appear underweight and unhealthy general condition which leads to opportunistic infections, recurrent administration of antibiotics and hospitalization. Also mothers of those children always appear depressed and have guilty feeling about their children condition.

1.1 Aim of the study:

This study aimed to assess mothers' needs for their infants who have CL and/or CP.

1.2 Research question:

What are the mothers' needs for their infants who have CL and/or CP?

1.3 Operational definition:

Mothers' needs in the current study means care needed regarding CL and/or CP and developmental needs of their infants.

\section{Methods}

2.1 Research design: Descriptive exploratory design was utilized in this study.

2.2 Research setting: The study was carried out in the inpatient department and outpatient clinic in two hospitals in Ismailia City, Suez Canal University hospital and specialized university hospital.

2.3 Sample: convenience sample of 50 mothers of CL and/or CP infants recruited over 6 months period. Mothers' inclusion criteria: Mothers having infants with CL and/or CP regardless mothers' age and educational level, and attending the study settings. Infants' inclusion criteria: infant from birth to 1 year of age, and confirmed diagnosis of cleft lip and/or palate by pediatric surgeon. Exclusion criteria: Another congenital anomalies such as other GIT disorders as congenital hypertrophic pyloric stenosis, intestinal obstruction......etc, or chronic diseases as chronic blood disorders and bronchial asthma,......etc.

\subsection{Tools of data collection:}

Two tools were developed by the researchers after extensive review of literature ${ }^{[9]}$ and used to collect the study data.

Structured questionnaire sheet: This sheet was written in Arabic language to suit the understanding level of the mothers and to assess mothers' needs for their infants who have CL and/or CP. It consisted of two parts: the first part including the personal data and health history of the infants including age, gender, and diagnosis, also personal data of his/her mothers as age, educational level, consanguinity and residence. The second part including questions about mother's needs about feeding, prevention of complications as pneumonia, otitis media, underweight, and dental problems. Also mothers' needs related to how to deal with the infants' health problems.

Infant physical and psychological needs assessment form: This form was designed in English language to assess the general health condition of infants having CL and/or CP and it includes data about the infant's physical measure including weight, and developmental needs were assessed including love and security, warmth and comfort, feeding, sucking pleasure and sensory stimuli.

\subsection{Validity of study tools:}

The content validity was tested by a jury consisted of 3 professors and experts in pediatric nursing and medicine to ascertain that the tools was relevant, understood, and applicable; minor modifications were carried accordingly.

\subsection{Reliability:}

Reliability of infant physical and psychological needs assessment form already assured because it was adopted from (Hockenberry \& Wilson)

\subsection{Ethical Considerations:}

Written consent was obtained from children' mothers to participate in the current study after explanation of the aim of the study and their freedom to withdraw from the study at any time without any effect of the care provided to her child. Confidentiality of the information collected and anonymity is guaranteed. 


\subsection{Procedure:}

An official letter was sent from the faculty of nursing, Suez Canal University to the directors, heads of neonatal and pediatric departments of the study settings to obtain their permission to collect the current study data. An official permission was attained from the directors of the study settings and the heads of pediatric departments. The researcher met the mothers attended to the aforementioned hospitals and introduced himself to them. A full explanation about the nature and aim of the study was carried out to the mothers in order to obtain their cooperation. Written consent was obtained from children' mothers to participate in the current study. The researcher interviewed the mothers and filled the structured questionnaire sheet from each mother individually. Infant physical and psychological needs assessment form was fulfilled by the researcher through measuring the growth parameters by using weight scale, and measuring tape. Satisfactions of developmental needs were observed during the mother-infant interaction. The approximate time spent with each mother infant dual to complete the assessment was 25 to 35 minutes across one session. Data were collected from February to July 2016.

\section{Results}

Table 1: Frequency distribution of the infants and their mothers according to their demographic characteristics

\begin{tabular}{|c|c|c|}
\hline Items & Number (n) & Percentage (\%) \\
\hline $\begin{array}{c}\text { Age /month } \\
\bullet 1-<6 \\
\bullet 6-12\end{array}$ & $\begin{array}{l}28 \\
22\end{array}$ & $\begin{array}{l}56.0 \\
44.0\end{array}$ \\
\hline Mean age $\pm S D / m o s$ & \multicolumn{2}{|c|}{$5.7 \pm 3.4$} \\
\hline Mean of current weight \pm SD $/ \mathrm{kg}$. & \multicolumn{2}{|c|}{$5.8 \pm 1.9$} \\
\hline $\begin{array}{r}\text { Infant gender } \\
-\quad \text { Male } \\
-\quad \text { Female }\end{array}$ & $\begin{array}{l}32 \\
18\end{array}$ & $\begin{array}{l}64.0 \\
36.0\end{array}$ \\
\hline $\begin{array}{l}\text { Diagnosis } \\
\text { - Cleft palate } \\
\text { - Cleft lip } \\
\text { - Cleft lip and palate }\end{array}$ & $\begin{array}{l}24 \\
15 \\
11\end{array}$ & $\begin{array}{l}48.0 \\
30.0 \\
22.0\end{array}$ \\
\hline $\begin{array}{c}\text { Age of mothers /years } \\
- \text { Less than } 20 \\
\therefore 20->30 \\
\cdot 30-<40 \\
\end{array}$ & $\begin{array}{c}3 \\
36 \\
11\end{array}$ & $\begin{array}{l}6.00 \\
72.0 \\
22.0\end{array}$ \\
\hline $\begin{array}{l}\text { Educational level of mothers } \\
\text { - Illiterate } \\
\text { - Primary and preparatory } \\
\text { - Secondary education } \\
\text { - University education }\end{array}$ & $\begin{array}{c}17 \\
9 \\
8 \\
16\end{array}$ & $\begin{array}{l}34.0 \\
18.0 \\
16.0 \\
32.0\end{array}$ \\
\hline $\begin{aligned} \text { Residence } \\
\bullet \quad \text { Rural } \\
\bullet \quad \text { Urban }\end{aligned}$ & $\begin{array}{l}31 \\
19\end{array}$ & $\begin{array}{l}62.0 \\
38.0\end{array}$ \\
\hline $\begin{array}{l}\text { Consanguinity of parents } \\
\text { • Yes } \\
\text { - No } \\
\end{array}$ & $\begin{array}{l}24 \\
26\end{array}$ & $\begin{array}{l}48.0 \\
52.0\end{array}$ \\
\hline
\end{tabular}

Table (1) shows that $56 \%$ of infants were aged between 1 to less than 6 months of age, and the total sample mean score of infants' age was 5.7 \pm 3.4 months and the mean score of infants' current weight was $5.8 \pm 1.9$ $\mathrm{Kg}$., $64 \%$ of infants were males, $48 \%, 30 \%, 22 \%$ of infants are diagnosed as cleft palate, followed by cleft lip, and cleft lip and palate respectively. In relation to mothers, $34 \%$ of them were illiterate, while $32 \%$ were having university education, $62 \%$ of them live in rural areas, $48 \%$ of parents have positive consanguinity. 
Table 2: Mothers' needs related to pneumonia and otitis media care and prevention among their infants who have cleft lip and/or palate $(n=50)$

\begin{tabular}{|c|c|c|}
\hline Items & Number (n) & Percentage (\%) \\
\hline $\begin{array}{l}\text { Infant suffered from pneumonia } \\
\text { - Yes } \\
\text { - No } \\
\end{array}$ & $\begin{array}{l}18 \\
32 \\
\end{array}$ & $\begin{array}{l}36.0 \\
64.0\end{array}$ \\
\hline $\begin{array}{l}\text { Number of getting pneumonia }[\mathbf{n}=\mathbf{1 8}] \\
\text { - Once } \\
\text { - Twice and more } \\
\end{array}$ & $\begin{array}{c}8 \\
10\end{array}$ & $\begin{array}{l}44.4 \\
55.5\end{array}$ \\
\hline $\begin{array}{l}\text { Mother's role to prevent pneumonia } \\
\text { - Don't know } \\
\text { - Use special method of feeding } \\
\text { - Keep infant in sitting position during feeding } \\
\text { - Burp infant during and after feeding } \\
\end{array}$ & $\begin{array}{r}36 \\
6 \\
6 \\
2 \\
\end{array}$ & $\begin{array}{l}72.0 \\
12.0 \\
12.0 \\
4.00\end{array}$ \\
\hline $\begin{array}{l}\text { Infant suffered from otitis media } \\
\text { - Yes } \\
\text { - No } \\
\end{array}$ & $\begin{array}{l}29 \\
21\end{array}$ & $\begin{array}{l}58.0 \\
42.0\end{array}$ \\
\hline $\begin{array}{l}\text { Number of getting otitis media }[\mathbf{n}=\mathbf{2 9}] \\
\text { - Once } \\
\text { - Twice and more } \\
\end{array}$ & $\begin{array}{l}16 \\
13\end{array}$ & $\begin{array}{l}55.2 \\
44.8 \\
\end{array}$ \\
\hline $\begin{array}{l}\text { Mother's role to prevent otitis media } \\
\text { - Don't know } \\
\text { - Perform ear care } \\
\text { - Burp infant during and after feeding } \\
\text { - Keep infant in sitting position during feeding } \\
\end{array}$ & $\begin{array}{c}33 \\
11 \\
4 \\
2 \\
\end{array}$ & $\begin{array}{l}66.0 \\
22.0 \\
8.00 \\
4.00 \\
\end{array}$ \\
\hline $\begin{array}{l}\text { Duration of giving antibiotics /days } \\
\text { - Mean } \pm \mathrm{SD}\end{array}$ & \multicolumn{2}{|c|}{$3.4 \pm 2.7$} \\
\hline
\end{tabular}

Table (2) describes that $36 \%$ and $58 \%$ of the infants suffered from pneumonia and otitis media respectively, $55.5 \%$ and $44.8 \%$ of them got pneumonia and otitis media twice or more times respectively. In relation to mothers, $72 \%$ and $66 \%$ of the mothers did not know how to prevent pneumonia and otitis media respectively and the mean duration of giving antibiotics in case of infection was 3.4 days as reported by mothers.

Table 3: Relation between infants and their mothers personal data, feeding practices and incidence of pneumonia among the infants $(n=50)$

\begin{tabular}{|c|c|c|c|c|c|}
\hline \multirow{3}{*}{ Socio-demographic characteristics } & \multicolumn{4}{|c|}{ Infants suffered from pneumonia } & \multirow{3}{*}{ Significance } \\
\hline & \multicolumn{2}{|c|}{ Yes $(n=18)$} & \multicolumn{2}{|c|}{ No $(n=32)$} & \\
\hline & No. & $\%$ & No. & $\%$ & \\
\hline $\begin{array}{l}\text { Age (months) } \\
\cdot 1-<6 \\
\cdot 6-12\end{array}$ & $\begin{array}{c}5 \\
13\end{array}$ & $\begin{array}{l}27.8 \\
72.2\end{array}$ & $\begin{array}{c}23 \\
9\end{array}$ & $\begin{array}{l}71.9 \\
28.1\end{array}$ & $\begin{array}{l}\mathrm{X}^{2}=9.091 \\
\mathrm{P}=0.003^{*}\end{array}$ \\
\hline $\begin{array}{l}\text { Infant gender } \\
\text { - Male } \\
\text { - Female }\end{array}$ & $\begin{array}{c}13 \\
5\end{array}$ & $\begin{array}{l}72.2 \\
27.8\end{array}$ & $\begin{array}{l}19 \\
13\end{array}$ & $\begin{array}{l}59.4 \\
40.6\end{array}$ & $\begin{array}{l}\mathrm{X}^{2}=0.825 \\
\mathrm{P}=0.364\end{array}$ \\
\hline $\begin{array}{l}\text { Clinical diagnosis } \\
\text { - Cleft lip } \\
\text { - Cleft palate } \\
\text { - Cleft lip and palate }\end{array}$ & $\begin{array}{l}1 \\
9 \\
8\end{array}$ & $\begin{array}{c}5.6 \\
50.0 \\
44.4 \\
\end{array}$ & $\begin{array}{c}14 \\
15 \\
3\end{array}$ & $\begin{array}{c}43.8 \\
46.9 \\
9.3 \\
\end{array}$ & $\begin{array}{c}\mathrm{X}^{2}=12.065 \\
{ }^{\mathrm{MC}} \mathrm{P}=0.003^{*}\end{array}$ \\
\hline $\begin{array}{l}\text { Education of mothers } \\
\text { - Illiterate } \\
\text { - Basic } \\
\text { - Secondary education }\end{array}$ & $\begin{array}{l}6 \\
4 \\
2\end{array}$ & $\begin{array}{l}33.3 \\
22.3 \\
11.1\end{array}$ & $\begin{array}{c}11 \\
5 \\
6\end{array}$ & $\begin{array}{l}34.4 \\
15.6 \\
18.8\end{array}$ & $\begin{array}{l}X^{2}=0.720 \\
P=0.869\end{array}$ \\
\hline
\end{tabular}




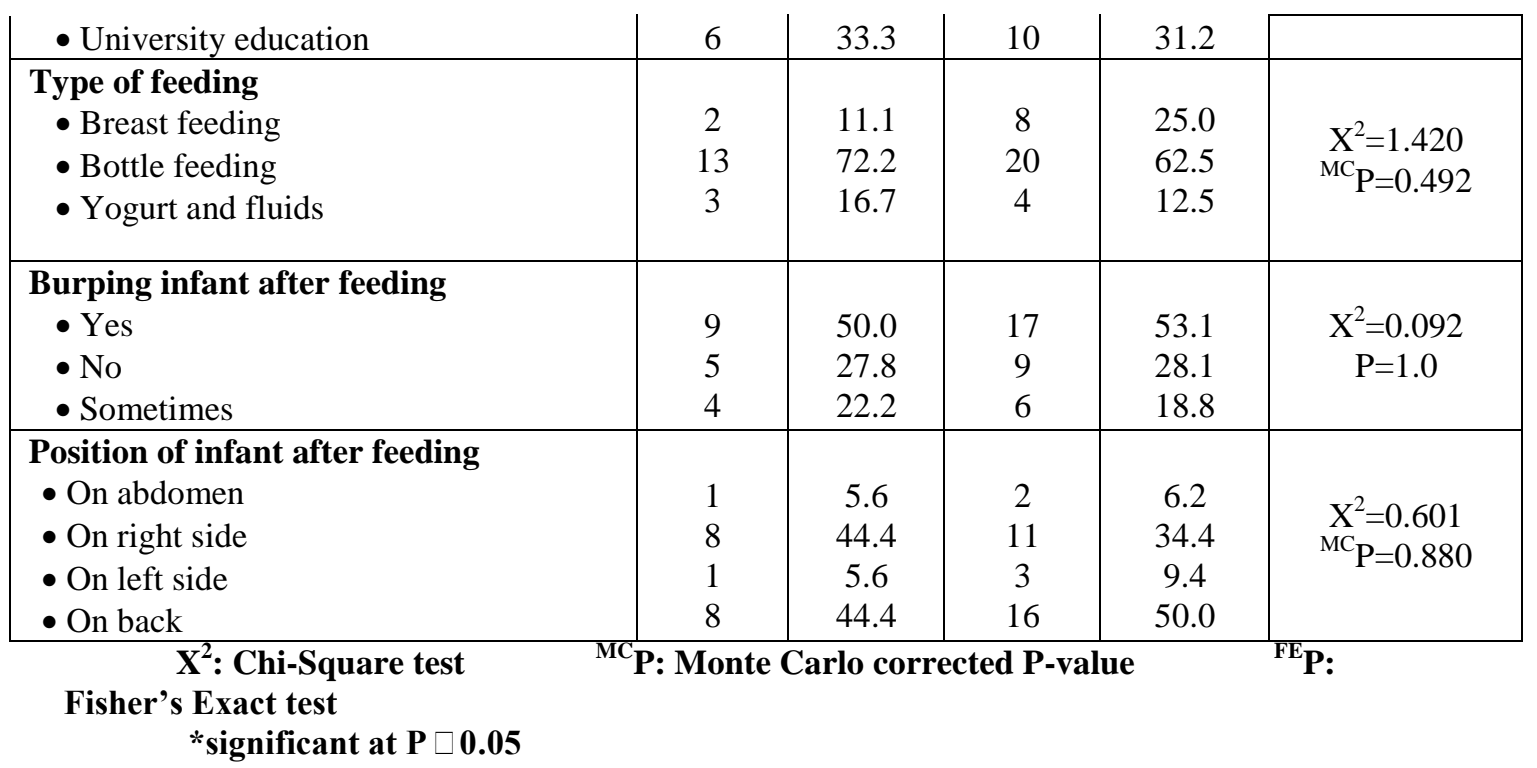

Table (3) clarifies that, $72.2 \%$ of the infants who suffered from pneumonia their age ranged from 6 to 12 months, $72.2 \%$ of the infants having pneumonia were males, $50 \%$ followed by $44.4 \%$ and $5.6 \%$ were diagnosed as cleft palate, both cleft lip and palate, and cleft lip respectively, the difference between groups was statistically significant. In relation to their mothers, $33.3 \%$ of them were illiterate, $72.2 \%$ were using bottle feeding, $50 \%$ were burping their infants after feeding and $44.4 \%$ were sleeping their infants on back after feeding.

Table 4: Relation between infants and their mothers personal data, feeding practices and incidence of otitis media among the infants $(\mathrm{n}=50)$

\begin{tabular}{|c|c|c|c|c|c|}
\hline \multirow{3}{*}{ Socio-demographic characteristics } & \multicolumn{4}{|c|}{ Infants suffered from otitis media } & \multirow{3}{*}{ Significanc } \\
\hline & \multicolumn{2}{|c|}{ Yes $(\mathbf{n}=29)$} & \multicolumn{2}{|c|}{ No $(\mathbf{n}=21)$} & \\
\hline & No. & $\%$ & No. & $\%$ & \\
\hline $\begin{array}{l}\text { Age (months) } \\
1-<6 \\
6-12\end{array}$ & $\begin{array}{l}14 \\
15\end{array}$ & $\begin{array}{l}48.3 \\
51.7\end{array}$ & $\begin{array}{l}14 \\
7\end{array}$ & $\begin{array}{l}66.7 \\
33.3\end{array}$ & $\begin{array}{l}X^{2}=1.672 \\
P=0.196\end{array}$ \\
\hline $\begin{array}{l}\text { Infant gender } \\
\text { Male } \\
\text { Female } \\
\end{array}$ & $\begin{array}{l}21 \\
8 \\
\end{array}$ & $\begin{array}{l}72.4 \\
27.6 \\
\end{array}$ & $\begin{array}{l}11 \\
10 \\
\end{array}$ & $\begin{array}{l}52.4 \\
47.6 \\
\end{array}$ & $\begin{array}{l}X^{2}=2.122 \\
P=0.145\end{array}$ \\
\hline $\begin{array}{l}\text { Clinical diagnosis } \\
\text { Cleft lip } \\
\text { Cleft palate } \\
\text { Cleft lip and palate }\end{array}$ & $\begin{array}{l}8 \\
14 \\
7\end{array}$ & $\begin{array}{l}27.6 \\
48.3 \\
24.1\end{array}$ & $\begin{array}{l}7 \\
10 \\
4\end{array}$ & $\begin{array}{l}33.3 \\
47.6 \\
19.1\end{array}$ & $\begin{array}{l}\mathrm{X}^{2}=0.279 \\
{ }^{\mathrm{MC}} \mathrm{P}=0.933\end{array}$ \\
\hline $\begin{array}{l}\text { Education of mothers } \\
\text { Illiterate } \\
\text { Basic } \\
\text { Secondary education } \\
\text { University education }\end{array}$ & $\begin{array}{l}8 \\
4 \\
8 \\
9 \\
\end{array}$ & $\begin{array}{l}27.6 \\
13.8 \\
27.6 \\
31.0 \\
\end{array}$ & $\begin{array}{l}9 \\
5 \\
0 \\
7\end{array}$ & $\begin{array}{l}42.9 \\
23.8 \\
0.0 \\
33.3 \\
\end{array}$ & $\begin{array}{l}\mathrm{X}^{2}=7.330 \\
{ }^{\mathrm{M} C} \mathrm{P}=0.062\end{array}$ \\
\hline $\begin{array}{l}\text { Type of feeding } \\
\text { Breast feeding } \\
\text { Bottle feeding } \\
\text { Yogurt and fluids }\end{array}$ & $\begin{array}{l}4 \\
20 \\
5\end{array}$ & $\begin{array}{l}13.8 \\
69.0 \\
17.2\end{array}$ & $\begin{array}{l}6 \\
13 \\
2\end{array}$ & $\begin{array}{l}28.6 \\
61.9 \\
9.5\end{array}$ & $\begin{array}{l}\mathrm{X}^{2}=1.940 \\
{ }^{\mathrm{MC}} \mathrm{P}=0.379\end{array}$ \\
\hline $\begin{array}{l}\text { Burping infant after feeding } \\
\text { Yes } \\
\text { No } \\
\text { Sometimes }\end{array}$ & $\begin{array}{l}15 \\
6 \\
8 \\
\end{array}$ & $\begin{array}{l}51.7 \\
20.7 \\
27.6 \\
\end{array}$ & $\begin{array}{l}11 \\
8 \\
2 \\
\end{array}$ & $\begin{array}{l}52.4 \\
38.1 \\
9.5\end{array}$ & $\begin{array}{l}X^{2}=3.306 \\
{ }_{\mathrm{MC}} \mathrm{P}=0.210\end{array}$ \\
\hline $\begin{array}{l}\text { Position of infant after feeding } \\
\text { On abdomen } \\
\text { On right side } \\
\text { On left side } \\
\text { On back }\end{array}$ & $\begin{array}{l}1 \\
11 \\
3 \\
14 \\
\end{array}$ & $\begin{array}{l}3.4 \\
37.9 \\
10.3 \\
48.4 \\
\end{array}$ & $\begin{array}{l}2 \\
8 \\
1 \\
10 \\
\end{array}$ & $\begin{array}{l}9.5 \\
38.1 \\
4.8 \\
47.6 \\
\end{array}$ & $\begin{array}{l}\mathrm{X}^{2}=1.225 \\
{ }^{\mathrm{MC}} \mathrm{P}=0.781\end{array}$ \\
\hline
\end{tabular}




\section{Exact test}

Table (4) shows that, $51.7 \%$ of the infants who suffered from otitis media were aged from 6 to 12 months, $72.4 \%$ of them were males, $48.3 \%$ had cleft palate. In relation to their mothers, $27.6 \%$ of them were illiterate followed by $13.8 \%$ had primary and preparatory education, $69 \%$ were using bottle feeding, $51.7 \%$ were burping their infants after feeding and $48.4 \%$ were sleeping their infants on back after feeding.

Table 5: Mothers' needs related to underweight, dental and speech problems care and prevention among their infants who have cleft lip and/or palate $(n=50)$

\begin{tabular}{|c|c|c|}
\hline Items & Number (n) & Percentage (\%) \\
\hline $\begin{array}{l}\text { Normality of current infant weight as perceived by } \\
\text { mothers } \\
\qquad \text { Yes } \\
\bullet \text { No }\end{array}$ & $\begin{array}{l}22 \\
28 \\
\end{array}$ & $\begin{array}{l}44.0 \\
56.0 \\
\end{array}$ \\
\hline $\begin{array}{l}\text { Causes of underweight as perceived by mothers } \\
\text { [n=28] } \\
\text { - Inability to take enough food } \\
\text { - Don't know } \\
\text { - Frequent aspiration }\end{array}$ & $\begin{array}{c}13 \\
10 \\
5\end{array}$ & $\begin{array}{l}46.4 \\
35.7 \\
17.9\end{array}$ \\
\hline $\begin{array}{l}\text { Complications resulting from underweight }[\mathbf{n}=\mathbf{2 8}] \\
\text { - Don't know } \\
\text { - Gastroenteritis } \\
\text { - Low immunity } \\
\text { - Delayed growth and development } \\
\end{array}$ & $\begin{array}{l}14 \\
6 \\
6 \\
2\end{array}$ & $\begin{array}{l}50.0 \\
21.4 \\
21.4 \\
7.2\end{array}$ \\
\hline $\begin{array}{l}\text { Mother's role to prevent underweight complications } \\
(\mathbf{n = 5 0 )} \\
\text { - Go to physician } \\
\text { - Don't know } \\
\text { - Do nothing }\end{array}$ & $\begin{array}{l}26 \\
13 \\
11\end{array}$ & $\begin{array}{l}52.0 \\
26.0 \\
22.0\end{array}$ \\
\hline $\begin{array}{l}\text { Type of dental problems }[\mathbf{n}=\mathbf{1 6}] \\
\text { - Delayed teeth eruption } \\
\text { - Abnormal teeth position } \\
\text { - Both }\end{array}$ & $\begin{array}{c}10 \\
4 \\
2\end{array}$ & $\begin{array}{l}62.5 \\
25.0 \\
12.5\end{array}$ \\
\hline $\begin{array}{l}\text { Mother's role toward occurrence of dental } \\
\text { problems }(\mathbf{n = 5 0}) \\
\text { - Follow up with dentist } \\
\text { - Don't know } \\
\text { - Do nothing }\end{array}$ & $\begin{array}{c}22 \\
22 \\
6\end{array}$ & $\begin{array}{l}44.0 \\
44.0 \\
12.0\end{array}$ \\
\hline $\begin{array}{l}\text { Saying one word at the end of one year }[\mathrm{n}=17] \\
\bullet \quad \text { Achieved } \\
\bullet \quad \text { Not achieved }\end{array}$ & $\begin{array}{c}2 \\
15\end{array}$ & $\begin{array}{l}11.8 \\
88.2\end{array}$ \\
\hline
\end{tabular}

Table (5) illustrates that $56 \%$ of infants' mothers perceive their infants' current weight was not suitable to their age and $46.4 \%$ of these mothers reported that the cause of underweight is the inability of child to take enough food. Also $50 \%$ of infants' mothers who have underweight infants did not know the complications of this condition and an equal percentage of $21.4 \%$ of them reported gastroenteritis and low immunity as the main complications of underweight, $52 \%$ of all mothers went to the physician to ask medical consultation while $26 \%$ and $22 \%$ of the mothers did not know and did nothing toward prevention of weight loss complications respectively. Regarding the dental problems as perceived by infants' mothers, $62.5 \%$ of the infants had delayed teeth eruption and $25 \%$ had abnormal teeth position. In addition, $44 \%$ and $12 \%$ of all mothers did not know and did nothing toward occurrence of dental problems. In relation to the infants who reached the age of vocalization, $88.2 \%$ of them do not say one word at the end of the first year.

Table 6: Relation between infants and their mothers personal data, feeding practices and incidence of weight loss among the infants $(n=50)$

\begin{tabular}{|l|c|c|c|c|c|}
\hline \multirow{2}{*}{ Items } & \multicolumn{3}{|c|}{ Underweight infants } & \multirow{2}{*}{ Significance } \\
\cline { 2 - 5 } & \multicolumn{2}{|c|}{ Yes (n=28) } & \multicolumn{2}{c|}{ No (n=22) } & \\
\cline { 2 - 5 } $\begin{array}{l}\text { Age (months) } \\
1-<6\end{array}$ & No. & & No. & \% & \\
\hline
\end{tabular}




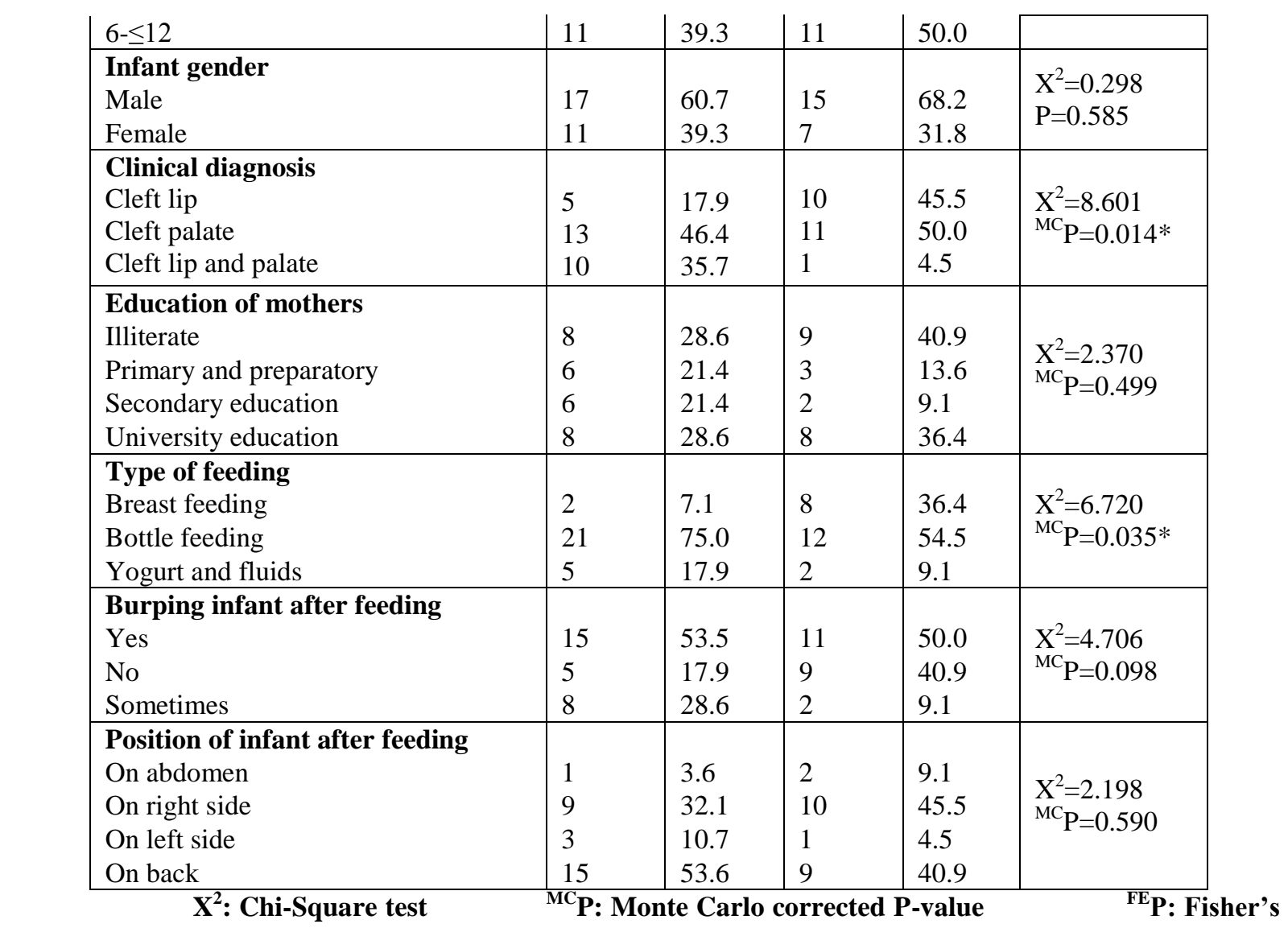

\section{Exact test}

$$
\text { *Significant at } \mathbf{P} \square \mathbf{0 . 0 5}
$$

Table (6) shows that in relation to infants who were underweight, $60.7 \%$ of them were aged from 1 to less than 6 months, $60.7 \%$ were males, $46.4 \%$ of them had cleft palate followed by $35.7 \%$ had both cleft lip and palate and $17.9 \%$ had cleft lip only and the difference between groups was statistically significant. In relation to their mothers, $28.6 \%$ of them were illiterate, $75 \%$ were using bottle for feeding, $53.5 \%$ were burping their infants after feeding and $53.6 \%$ were sleeping their infants on back after feeding.

Table 7: Satisfaction of developmental needs of the infants by their mothers $(n=50)$ 


\begin{tabular}{|c|c|c|}
\hline \#Der elopmentalneeds & Number (n) & Percentage (\%) \\
\hline $\begin{array}{l}\text { Love and security } \\
\text { - Mother cuddles her infant } \\
\text { - Mother kisses him } \\
\text { - Takes infant on her lap }\end{array}$ & $\begin{array}{l}31 \\
22 \\
16\end{array}$ & $\begin{array}{l}62.0 \\
44.0 \\
32.0\end{array}$ \\
\hline $\begin{array}{l}\text { Warmth and comfort\# } \\
\text { - None } \\
\text { - Wears infant suitable clothes } \\
\text { - Usang es diapers as needed } \\
\text { - Uses head cover and socks }\end{array}$ & $\begin{array}{l}11 \\
31 \\
13 \\
6\end{array}$ & $\begin{array}{l}22.0 \\
62.0 \\
26.0 \\
12.0\end{array}$ \\
\hline $\begin{array}{l}\text { Feeding\# } \\
\text { - Gives feeding as needed by infant } \\
\text { - Gives her infant scheduled feeding }\end{array}$ & $\begin{array}{l}36 \\
14\end{array}$ & $\begin{array}{l}72.0 \\
28.0\end{array}$ \\
\hline $\begin{array}{l}\text { Sucking pleasure } \\
\text { - None } \\
\text { - Makes sucking pleasure by breast feeding } \\
\text { - Gives infant her fing ers for sucking } \\
\text { - Let the infant to suck his fingers }\end{array}$ & $\begin{array}{c}13 \\
4 \\
23 \\
2 \\
8\end{array}$ & $\begin{array}{c}26.0 \\
8.0 \\
46.0 \\
4.0 \\
16.0\end{array}$ \\
\hline $\begin{array}{l}\text { Sensory stimuli\# } \\
\text { - None } \\
\text { - Talks to her infant } \\
\text { - Touches the back and different body parts } \\
\text { - Provides the child with preferred food }\end{array}$ & $\begin{array}{l}12 \\
27 \\
18 \\
20\end{array}$ & $\begin{array}{l}24.0 \\
54.0 \\
36.0 \\
40.0\end{array}$ \\
\hline \multicolumn{3}{|c|}{ Developing sense of trust } \\
\hline $\begin{array}{c}\text { Dev eloping sense of trust } \\
\text { - Yes } \\
\text { - No }\end{array}$ & $\begin{array}{c}50 \\
0\end{array}$ & $\begin{array}{c}100.0 \\
0.0\end{array}$ \\
\hline
\end{tabular}

\section{\#Items of developmental needs are not mutually exclusive}

Table (7) shows that $62 \%$ of the infants' mothers were cuddling their infants followed by $44 \%$ were kissing their infants to show love and security to their infants. In relation to warmth and comfort, $62 \%$ of the mothers were wearing their infants' suitable clothes, while $22 \%$ were not achieving satisfaction of warmth and comfort needs to their infants. Also $28 \%$ of the mothers were giving their infants scheduled and weaning foods to satisfy their feeding needs. In order to satisfy their sucking pleasure, $46 \%$ of the mothers were using pacifier, while $26 \%$ of them did not use any method to satisfy sucking pleasure needs of their infants. According to satisfaction of sensory stimuli, 54\% of the mothers were talking to their infants, while $24 \%$ of them were not making sensory stimuli to their infants, $100 \%$ of infants had sense of trust.

\section{Discussion}

The current study results revealed that slightly less than three quarters, about two third, slightly more than one quarter, and more than two fifth of the mothers were unaware about their role to prevent pneumonia, otitis media, the complications of weight loss and care of the dental problems respectively. In relation to developmental needs, more than one fifth, more than one quarter and slightly less than one quarter of the mothers were not achieving satisfaction of warm/comfort, sucking pleasure and sensory stimuli needs to their infants respectively. These results answered the research question and specify the mothers' needs for their infants who have cleft lip and/or palate.

The current study revealed that more than one third of the mothers reported the occurrence of pneumonia among their infants and more than half of these infants had recurrent pneumonia twice or more. These results in accordance with the study about "mortality among infants had born with orofacial clefts in a single cleft network"; the study findings concluded that slightly less than one fifth of the infants died due to pneumonia and they recommended to improve services provided by specialist cleft network ${ }^{[11]}$.

The study results showed that slightly less than three quarter and half of the infants who suffered from pneumonia were aged between 6 to 12 months and diagnosed as cleft palate respectively. These findings were in accordance with ${ }^{[12]}$ who concluded that more than one third of one hundred infants had aspiration pneumonia with more frequency among infants with cleft palate after performing their study about "the incidence of aspiration pneumonia in infants with cleft palate". The faulty position (on the child back) especially after feeding in less than half of infants having pneumonia may be acts one of the predisposing factors to aspirate the food content causing pneumonia.

In relation to mothers of infants who suffered from pneumonia, the current study findings revealed that slightly less than three quarter of total sample did not know how to prevent pneumonia. These results were supported by ${ }^{[13]}$ who emphasized that babies with a cleft palate have a higher incidence of intercurrent infections, particularly lower respiratory tract infections. Also, these results were in accordance with ${ }^{[14]}$ who studied "perceived barriers to care among children with orofacial clefts in North Carolina" and concluded that 
structural barriers were cited by $26.5 \%$ of the respondents, impeding their child's receipt of services a lack of adequate and user-friendly health information or families caring for children with OFC. These results may be due to mothers' illiteracy.

The results of the current study showed that slightly less than two third of mothers reported that the mean score of duration of giving antibiotics for treating pneumonia and/ or otitis media is $3.4 \pm 2.7$ days, while ${ }^{[15]}$ recommended that several types of antimicrobial medications to treat pneumonia in children should be given either intravenous or oral for 10 to 14 days continuously. Also the financial barriers in caring for orofacial defects were summarized among $20 \%$ of the respondents; as not having adequate health insurance coverage; limited resources for payment for health services; and lack of tools or equipment for the care of their child ${ }^{[14]}$. Other financial constraints stated by respondents included the family's overall financial state, high out-of-pocket expenses, and lost time from work due to the child's need for craniofacial and cleft care. Also structural barriers were cited by $26.5 \%$ of the respondents, reporting lack of adequate health information for caring for children with OFC. From the researchers' point of view, this short period of giving antibiotics may be for financial causes because the complete course may need more than two packets of medications, therefore the health insurance for all children should be effectively enabled.

The current study indicated that three fifth of the mothers reported the occurrence of otitis media infections among their infants, less than half of these infants had recurrent otitis media infections twice or more and the cleft palate followed by cleft palate and lip infants are the most affected group, these results were supported by ${ }^{[16]}$ which reported that ear infections are very common in children with cleft palate, also studies in the United States shows that nearly all children born with cleft palate will have problems with their ears at some time, about half of those children will have recurring ear infections before they are one year old.

In relation to the mothers of infants who suffered from otitis media, results of the current study revealed that slightly less than half of them were sleeping their infants on back after feeding; in contradiction with ${ }^{[17]}$ who emphasized that prone sleeping position is considered the best to reduce risk of otitis media in infants and young children. In addition, the results of the current study showed that about two thirds of the mothers did not know how to prevent otitis media and these results were in accordance with ${ }^{[18]}$ who assessed parents' beliefs and knowledge about the management of acute otitis media and their results concluded that many parents did not have an accurate understanding about management of otitis media.

In relation to mothers' needs regarding underweight infants, the current study indicated that three fifth of the infants were underweight when comparing their age to the current weight through the assessment done by the researchers and this finding was in the same line with ${ }^{[13]}$ who emphasized that babies with a cleft palate significantly malnourished and require perioperative nutritional support, also ${ }^{[19]}$ found that infants with cleft lip and palate were highly susceptible to weight loss and gastroenteritis. These results may be due to the feeding difficulties arisen, and the recurrent opportunistic infections like pneumonia and gastro-entritis.

Regarding infants who were underweight, the results of the present study showed that about three fifth of them were aged less than 6 months and this result was in accordance with ${ }^{[20]}$ in a study titled "weight gain in children with cleft lip and palate" and their results concluded that children with cleft palate weigh less than regular children during their first months of life and also both genders remained at the $50^{\text {th }}$. percentile (p.50) and improved after the six month of age. The results may be due physiological causes as lack of digestive enzymes as amylase and saliva is secreted in a small amount at the early 3 months of age, in addition to presence of OFCs.

The current study showed that about three fifth of the infants who were underweight were males and also slightly less than half of them were diagnosed as cleft palate. These findings were in the same line with ${ }^{[21]}$ who search "mortality rates among children with cleft lip and palate" and found that sex distribution followed the classic pattern of male predominance higher than female predominance in losing weight among children with cleft palate. In addition, these findings were in the same line with ${ }^{[22]}$ who evaluated "weight gain and feeding in the neonate with clefts" and found that variations in weight gain by cleft type show considerable differences between the CL group, CLP, CP group, with the CP group showing the lowest rate of weight gain. The male predominant gender may be due to they are high risk group for higher proportions of diseases and defects.

Although three quarters of mothers of the underweighted infants were using bottle to feed their infants; the majority of them were using special method for feeding; more than half were burping their infants during and after feeding, but three fifth of the infants had underweight. From the researcher point of view this is due to the nature of the anomaly which influences the infant's ability to create enough intraoral pressure needed for adequate feeding and also since slightly less than three quarters of the mothers who were using bottle feeding were giving formula to their infants every more than 3 hours per time which may be passively affect infants weight gain.

In relation to mothers' needs toward dental problems, the results of the current study revealed that that more than three fifth and one quarter of the infants had delayed teeth eruption and abnormal position 
respectively; these findings were in accordance with ${ }^{[23]}$ in a study titled "timing and sequence of primary tooth eruption in children with cleft lip and palate" the results revealed that children with clefts presented a higher mean age of eruption of all primary teeth for both arches and both genders, compared to children without clefts and suggested an interference of the cleft on the timing of eruption of primary teeth.

The current study results showed that more than two fifths of the mothers indicated that their role toward occurrence of dental problems including follow up with dentist, while another two fifth of them did not know their role. These results were in the same line with ${ }^{[24]}$ who observed that the perception and attitudes related to oral health in children with clefts were significantly different between families with or without knowledge. From the researcher point of view good dental care is essential, these children have an increased need for preventive and restorative dental care due to underlying dental anomalies during 5-24 months of their early age; also the parents must monitor eruption of teeth.

In relation to satisfaction of infants' developmental needs, the findings of the current study revealed that more than one fifth of the mothers were not achieving satisfaction of warmth and comfort needs to their infants; these results were not in accordance with ${ }^{[25]}$ who emphasized that warmth and comfort are the most powerful personality traits in social judgment, and attachment; theorists have stressed the importance of warm physical contact with caregivers during infancy for healthy relationships in adulthood.

The current study showed that about one quarter of the mothers did not use any method to satisfy sucking pleasure needs of their infants. This finding was disagreed with ${ }^{[26]}$ who described that all healthy newborns start life and sustain it with an urge to suck. For many infants, the sucking instinct is not satisfied by feedings alone. Non-nutritive sucking, that is sucking thumbs, fingers, pacifiers and other objects, is a healthy normal behavior and offers young children a feeling of security, comfort, pleasure and relaxation during the first few years of life.

The current study revealed that about one quarter of the mothers was not making sensory stimuli to their infants. This result is disagreed with ${ }^{[27]}$ who illustrated that infants and toddlers use their senses to take in stimuli from the environment and respond through reflexes and motor activity. They are learning about their world through tasting, touching, seeing, hearing, and smelling. For each child, the senses initiate, propel, and refine fine and gross muscles into practiced balance, precision, coordination, agility, and stability. From the researcher point of view, satisfying of developmental needs for infants with cleft lip and/or palate by their mothers is crucial especially during the first few years of life in order to improve health, growth and development.

\section{Conclusion}

Research data concluded that mothers' needs for their infants who have cleft lip and/or palate are numerous even related to orofacial defects and developmental needs. The study concluded that some of the mothers unaware of their roles regarding prevention of pneumonia, otitis media, complications of underweight, and also how to care for their infants dental problems. In addition, some mothers did not satisfy the basic developmental needs of their infants as love, security, sucking pleasure and sensory stimuli needs.

The study recommended that:

\section{Recommendations}

1. Developmental needs and problems of infants with cleft lip and/or palate should be taken into considerations in planning for infants' care.

2. Educational program should be designed and implemented for those infants' mothers.

3. Encourage and enable fathers to share responsibility during the course of education.

4. Further researches should be conducted to provide interventional modalities to reduce mother's needs as well as booklets for education.

\section{References}

[1]. Oginni, F., \& Adenekan, A. Prevention of Orofacial Clefts in Developing World, Cleft Palate Craniofacial Journal; (2012), 2(2):163-169.

[2]. Watkins, S., Meyer, R., Strauss, R \& Aylsworth, A. Classification, Epidemiology, and Genetics of Orofacial Clefts, Clinics in Plastic Surgery; (2014), 41(2):63-149.

[3]. Shawky, R., Sadik ,D. Congenital Malformations Prevalent Among Egyptian Children and Associated Risk Factors, The Egyptian Journal of Medical Human Genetics, Ain Shams University; (2011), 12(69):71.

[4]. Sinno, H., Tahiri, Y., Thibaudeau, S., Izadpanah ,A., Christodoulou, .G., et al. Cleft Lip and Palate: An Objective Measure Outcome Study. PlastReconstrSurg; (2012), 130 (2): P.P. 408-14.

[5]. Azim, S. The Quality of Life in The Patients After Cleft Palate Surgery; (2014), Vol.(13), No.(2), P.64

[6]. Buchman, S., Kasten, S \& Walborn, C. (2011). Repair of Cleft Lip and Palate, A Parent's Guide, Craniofacial Anomalies Program, The Regents of The University of Michigan. P.2.

[7]. Ball, J., Bindler, R \& Cowen, K. (2012). Principles of Pediatric Nursing, Caring for Children, $5^{\text {th }}$ ed, Pearson Company, P.73.

[8]. Chuacharoen, R., Ritthagol, W., Hunsrisakhun, J., Nilmanat, K. Felt Needs of Parents who have a 0- to 3-Month-Old Child with a Cleft Lip and Palate, Cleft Palate-Craniofacial Journal; (2010), 46(3):254. 
[9]. Hockenberry, M \& Wilson, D. (2013): Wong's Essentials of Pediatric Nursing , $9^{\text {th }}$ ed, The CV Mosby Company: Canada, pp.308309.

[10]. El-Wasefy, S. (2009): Need Assessment of Mothers Having Child Suffering From Cleft Lip and Palate, Unpublished Master Degree in Nursing Thesis, Faculty of Nursing, Mansoura University, pp.114-115.

[11]. Kang, S., Narayanan, C., Kelsall, W. Mortality among Infants Born with Orofacial Clefts in a Single Cleft Network, The Cleft Palate-Craniofacial Journal; (2012), 49(4):509.

[12]. Hun, L., Won, C., Chol, J., Ki, P and Il, U. Aspiration Pneumonia in Patients with Cleft Palate. Journal of the Korean Radiological Society; (2016), 48(3): 289-293.

[13]. Cubitt, J., Hodges, A., Van Lierde, K., Swan, M. Global Variation in Cleft Palate Repairs: An Analysis of 352,191 Primary Cleft Repairs in Low- to Higher-Middle-Income Countries, The Cleft Palate-Craniofacial Journal; (2014), 51(5): 553-556.

[14]. Cassell, C., Mendez, D., Strauss, R. Maternal Perspectives: Qualitative Responses About Perceived Barriers to Care Among Children With Orofacial Clefts in North Carolina, Cleft Palate-Craniofacial Journal; (2012), 46(3):262-269.

[15]. Ostapchuk, M., Roberts, D., Haddy, R. Community-Acquired Pneumonia in Infants and Children, American Academy of Family Physicians; (2012), 70(5):905.

[16]. Cleft Palate Foundation, (2015): Help with Hearing, Chapel Hill, NC, Available at: www.cleftline.org/docs/Booklets/HRG-01.pdf Accessed on: $7 / 1 / 2017$.

[17]. Donaldson, J. (2016): Acute Otitis Media. Available at: http://emedicine.medscape.com/article/859316-overview. Accessed on: 20/3/2017.

[18]. Hansen, M., Howlett, J., Mar, C., Hoffmann, T. (2015): Parents' beliefs and knowledge about the management of acute otitis media: a qualitative study, available at: http://bmcfampract.biomedcentral.com/articles/10.1186/s12875-015-0297-7. Accessed on: 20/3/2017.

[19]. Zhang, Z., Fang, S., Zhang, Q., Chen, L., Liu, Y., Li, K., Zhao, Y. Analysis of Complications in Primary Cleft Lips and Palates Surgery. J Craniofac Surg; (2014), 25(3):968-71.

[20]. Freitas, R., Lopes-Grego, A., Dietrich, H and et al. Weight Gain in Children with Cleft Lip and Palate without Use of Palatal Plates, Plastic Surgery International J; . (2012), 102(2):1

[21]. Mackeprang, M., Hay, S. (2013): Mortality Rate among Cleft Lip and Palate Children. Available at: https://www.jultika.oulu.fi/files/isbn9789526212739.pdf Accessed on: 20/3/2017.

[22]. Jones, W. Weight Gain and Feeding in the Neonate with Cleft, Cleft Palate J; (2014), 25(4):382.

[23]. Kobayashi, T., Gomide, M., Carrara, C. Timing and Sequence of Primary Tooth Eruption in Children with Cleft Lip and Palate, Journal of Applied Oral Science; (2013), 18(3):17.

[24]. Adair, P., Pine, C., Burnside, G., et al. Familial and Cultural Perceptions and Beliefs of Oral Hygiene and Dietary Practices among Ethnically and Socio-economically Diverse Groups. Community Dent Health; (2004), 21:102-111.

[25]. Williams, L \& Bargh, J. (2008): Experiencing Physical Warmth Promotes Interpersonal Warmth, available at: https://www.ncbi.nlm.nih.gov/pmc/articles/PMC2737341/ Accessed on: 5/11/2016.

[26]. Lucich, (2014): Thumb, Finger or Pacifier Sucking. California Childcare Health Program, available at: http://cchp.ucsf.edu/sites/cchp.ucsf.edu/files/thumbsen1105_adr.pdf Accessed on: 5/1/2017.

[27]. Parks, Sensorimotor Development: Hands-on Activities for Infants and Toddlers, Texas Child Care quarterly; (2014), $37(4): 18$. 